\title{
Important issues in select European Union countries' criminal environmental law in compliance with Directive 2008/99/EC
}

\author{
E. Zębek \\ University of Warmia and Mazury in Olsztyn, \\ 1, Obitza, Olsztyn, 10-725, Poland
}

For citation: Zębek, Elżbieta. 2021. “Important issues in select European Union countries' criminal environmental law in compliance with Directive 2008/99/EC". Vestnik of Saint Petersburg University. Law 2: 356-373. https://doi.org/10.21638/spbu14.2021.207

This article analyzes issues in criminal environmental law in Poland, the Czech Republic and Germany, which implemented the provisions of the European Commission Directive 2008/99/ EC. The provisions of this directive changed the scope of protection of environmental resources in these countries' penal codes to varying extents. These three countries have been relatively successful in comprehensively implementing criminal directive provisions. This included changes in the special protection of Natura 2000 sites and ozone depleting substances. Legal systems are generally based on prevention and risk assessment, and the basic conditions of criminal responsibility for environmental crimes include "significant damage, causing damage to the health of another or animals and plants, damage to other property and also water, air, soil and environmental components which have significant value". Additional aspects include environmental damage over larger areas and restoration costs. However, the greatest current problem is the vague definition of conditions of criminal responsibility, which makes it difficult to enforce legislation. The following postulates de lege ferenda were formulated: clarify the premises for offenses against the environment, specify the costs of remedying environmental damage, define critical emission standards for environmental crime, as well as specify activities in protected areas that threaten objects. This article emphasizes that an increased and better definition of the conditions of criminal responsibility for environmental crimes enacted by EU countries may contribute to more effective enforcement of infringements of environmental protection law.

Keywords: criminal environmental law, implementation of provisions, system of national law, environmental resources, legally protected areas, crimes against environment, conditions of criminal responsibility.

(C) St. Petersburg State University, 2021 


\section{Introduction}

The principles of European Union (EU) criminal-law environmental protection are regulated in Directive 2008/99/EC of the European Parliament and of the Council of 19 November 2008 on the protection of the environment through criminal law ${ }^{1}$. The directive focuses on the consolidation of criminal law and the "Europeanization" of environmental protection (Gouritin, de Hert 2009). The main premise for its adoption is that "the Community is concerned at the rise in environmental offences and at their effects which are increasingly extending beyond the borders of the State in which the offences are committed. Such offences pose a threat to the environment and therefore an appropriate response" is required. Illegal acts with a significant negative impact on the environment can be transboundary. Included here are the emissions of pollutant gas and dust into the air as well as toxic substances entering waterways and soil from illegal sewage discharge and waste storage. The offenses pose a threat to humans and the environment and therefore require an appropriate and adequate response with severe criminal sanctions. The directive obliges member states to introduce criminal penalties in their national legislations for serious infringements of Community Law on environmental protection, and these criminal penalties should be proportionate, dissuasive and effective (Keene 2015; Farmer, Faure, Fagliasindi 2017).

Article 3 of the directive sets out a list of acts considered environmental offenses. The following acts committed unlawfully and intentionally or resulting from serious negligence are identified:

- the discharge, emission or introduction of a quantity of materials or ionising radiation into air, soil or water which causes or is likely to cause death or serious injury to any person or substantial damage to the quality of air, the quality of soil or the quality of water, or to animals or plants;

- the collection, transport, recovery or disposal of waste, including the supervision of such operations and the aftercare of disposal sites, and including action taken as a dealer or a broker (waste management), which causes or is likely to cause death or serious injury to any person or substantial damage to the quality of air, the quality of soil or the quality of water or to animals or plants;

- the shipment of waste, where this activity falls within the scope of Article 2(35) of Regulation (EC) No. 1013/2006 of the European Parliament and of the Council of 14 June 2006 on shipments of waste ${ }^{2}$ and is undertaken in a non-negligible quantity, whether executed in a single shipment or in several shipments which appear to be linked;

- the operation of a plant in which a dangerous activity is carried out or in which dangerous substances or preparations are stored or used and which, outside the plant, causes or is likely to cause death or serious injury to any person or substantial damage to the quality of air, the quality of soil or the quality of water, or to animals or plants;

${ }^{1}$ Directive 2008/99/EC of the European Parliament and of the Council of 19 November 2008 on the protection of the environment through criminal law (OJ L 328, 06.12.2008, p. 28-37). 2008. Accessed September 12, 2019. https://eur-lex.europa.eu/legal-content/EN/TXT/?uri=CELEX\%3A32008L0099.

2 Regulation (EC) No. 1013/2006 of the European Parliament and of the Council of 14 June 2006 on shipments of waste (OJ L 190, 12.07.2006, p.1-98). 2006. Accessed September 12, 2019. https://eur-lex. europa.eu/legal-content/EN/ALL/?uri=CELEX\%3A32006R1013. 
- the production, processing, handling, use, holding, storage, transport, import, export or disposal of nuclear materials or other hazardous radioactive substances which causes or is likely to cause death or serious injury to any person or substantial damage to the quality of air, the quality of soil or the quality of water, or to animals or plants;

- the killing, destruction, possession or taking of specimens of protected wild fauna or flora species, except for cases where the conduct concerns a negligible quantity of such specimens and has a negligible impact on the conservation status of the species;

- trading in specimens of protected wild fauna or flora species or parts or derivatives thereof, except for cases where the conduct concerns a negligible quantity of such specimens and has a negligible impact on the conservation status of the species;

- any conduct which causes the significant deterioration of a habitat within a protected site;

- the production, importation, exportation, placing on the market or use of ozonedepleting substances.

Illegal acts classified as environmental crimes are divided into two specific groups: 1) crimes related to the natural environment and 2) crimes caused by the emission of pollutants into the environment. The first group includes acts of trading, killing, destroying, possessing and taking specimens from protected wild fauna and flora species and activities causing significant deterioration to natural habitats. The second group covers activities involving the emission of particularly harmful substances to the environment including ionizing radiation emission into air, water and soil, inadequate waste management and shipment, dangerous substances and preparations, nuclear materials and other hazardous radioactive substances and ozone-depleting substances. The qualification for offense severity is that they cause death or serious injury to any person or substantial damage to air, water or soil quality or to animals or plants (Cardwell French, Hall 2011) ${ }^{3}$. However, the directive imposes no restrictions on the manner of applying these sanctions or any other existing system of law enforcement in individual cases, and this provides great freedom in implementing the directive's provisions in national laws of member states. Although the directive was intended to ensure the specifics of comprehensive environmental protection, available literature has highlighted many problems in both implementing and interpreting the directive's regulations in EU countries (Faure, Weber 2017).

This article analyzes the directions for implementing Directive 2008/99/EC provisions in EU countries of Poland, the Czech Republic and Germany. It also determines the impacts of its implementation on these countries' environmental crime regulations in their penal code. The subject of the analysis is environmental crime in the selected EU countries which are obliged to implement the directive's provisions. The abovementioned countries were chosen due to their proximity. Poland, the Czech Republic and Germany are neighbouring countries and their pollutant emissions may be transboundary. It is also noteworthy that these countries have implemented and expanded the scope of environ-

3 "Strategic Project on Environmental Crime, Report". 2014. EUROJUST. Accessed December 4, 2019. http://environmental-crime-report_2014-11-21-EN.pdf; "Environmental crime and the EU. Synthesis of the Research Project 'European Union Action to Fight Environmental Crime"'. 2016. EFFACE. Accessed December 4, 2019. https://efface.eu. 
mental crime differently in their penal codes. This is despite Germany being a European Union founding state and Poland and the Czech Republic joining the EU in 2004. The article is based on an analysis of the literature and legal acts on the subject and the use of formal-dogmatic and legal-comparative methods.

\section{Basic research}

\subsection{General issues of directive implementation}

The resolution of Directive 2008/99/EC was implemented in Poland in the Penal Code of 6 June 1997 (LJ of 2019, item 1950, 2128) - PPC Chapter XXII Articles 181-188 "Offenses against the environment"4 The legislated crimes are "Destruction, Pollution, Waste, Radioactive material, Significant act, Unperformed duty, Protected area or object and Harmful activity". These provisions are general in nature, but they comprehensively relate to the most serious types of behavior that are detrimental to the natural environment (Zawłocki 2014). The offenses in this chapter can be divided into two groups: 1) offenses against the natural environment committed under Articles 181, 187 and 188 and 2) the offense of causing pollution to the air, water and soil environments under Articles 182186 (Radecki 2010a). Poland has implemented Directive 2008/99/EC by introducing new legal provisions against air, water and soil pollution by a substance or their contamination by ionizing radiation under Article182. Article 183 legislates the new criminal provisions for inadequate waste management and shipment (Raniszewski 2012).

Environmental offenses in the Czech Republic are regulated in Chapter VIII Sections 293-308 of the 2009 Penal Code (Zakon č. 40/2009 Sb.) - CPC for "Criminal of-

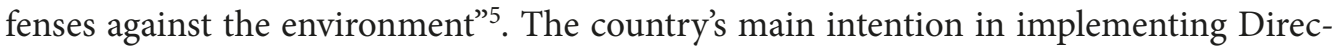
tive 2008/99/EC was similar to that of Poland. It aimed to strengthen criminal liability for damage or threat to individual environmental components, including the air, water and soil. The code penalizes illegal acts which cause damage to the environment and its components and water resources. This covers damage from harmful waste and substances, such as radioactive elements and their illegal shipment. The code also defines criminal liability for damage caused to the environment, with particular emphasis on criminal law protection of water resources and Natura 2000 sites (Stejskal 2010; Jančaŕová 2011; Mizerová 2011).

Crimes against the environment in Germany are regulated under Chapter 29 of the 1998 Penal Code (Federal Law Gazette I, p. 3322) - GPC "Offences against environment"6. This catalogue of crimes has a much wider scope than those in Poland and the Czech Republic. It includes 13 sections on water, soil and air pollutions, causing noise, vibrations and non-ionising radiation, unauthorized waste management, operation of facilities and handling of radioactive substances and other hazardous substances and goods, endangering protected areas and other serious offences against the environment. German

${ }^{4}$ Ustawa z dnia 6 czerwca 1997 r. Kodeks karny (tj. Dz. U. z 2019, poz. 1950, 2128). 1997. Accessed September 12, 2019. https://isap.sejm.gov.pl/isap.nsf/download.xsp/WDU19970880553/U/D19970553Lj. pdf.

5 Zákon ze dne 8. ledna 2009 trestní zákoník (Zakon č. 40/2009 Sb.). 2009. Accessed September 12, 2019. https://www.zakonyprolidi.cz/cs/2009-40?text.

${ }^{6}$ Strafgesetzbuch in der Fassung der Bekanntmachung vom 13. November 1998 (BGBl. I S. 3322). 1998. Accessed September 12, 2019. http://www.gesetze-im-internet.de/stgb/StGB.pdf. 
environmental criminal law is a typical example of a modern legal system based on prevention and risk assessment. Although Germany has made constant additions and changes to its environmental legislation, it still has vague legislative terminology and lacks a definition seen in the other European countries. This results in significant difficulties in enforcing criminal law provisions in an appropriate and coherent manner (Kloepfer, Vierhaus 2002, 167; Weber 2014; Sina 2014; Sina 2017).

\subsection{Crimes against natural environmental values}

Directive 2008/99/EC obliges the member states to introduce legal regulations for protection of the natural environment in criminal law in order to safeguard them more effectively. These crimes are included in Article 3 points $\mathrm{f}, \mathrm{g}$ and $\mathrm{h}$, and they legislate against the destruction of wild flora and fauna and natural habitat species, including those under legal protection and also all trading in protected wild flora and fauna.

The protected wild flora and fauna species are listed in: 1) Annex IV of Council Directive $92 / 43 / \mathrm{EEC}$ of the $21^{\text {st }}$ of May 1992 on the conservation of natural habitats and wild flora and fauna 72 ) Annex I of Council Directive 79/409/EEC of the $2^{\text {nd }}$ of April 1979 for the conservation of wild birds ${ }^{8}$ and 3) Annex A or B of Council Regulation (EC) No. 338/97 of the $9^{\text {th }}$ of December 1996 for the protection of wild flora and fauna species ${ }^{9}$ and their natural habitats classified as a special protection area pursuant to Article 4 (1) or (2) of Directive 79/409/EEC or habitats designated as a special conservation area pursuant to Article 4 (4) of Directive 92/43/EEC ${ }^{10}$.

In Poland, crimes against natural environment values are regulated in Articles 181, 187 and 188 of the PPC. The legislated crimes are 'Destruction, Protected area or object and Harmful activity. The group of sanctioned offenses currently in force covers the destruction of natural heritage by actions resulting in significant destruction to the plant and animal world. Here, Articles $181 \S 1$ and 2 outline the two conditions of criminal responsibility for plant and animal destruction. The first condition is causing 'damage of significant size' and the second is 'significant damage in protected areas'. Article 181 penalizes the following acts: significant destruction to plant or animal life $(\$ 1)$, violation of the provisions in force in a protected area $(\$ 2)$, and destruction or damage of plants or animals causing serious harm $(\$ 3)$. Article $181 \S 1$ employs the first condition of responsibility for crimes against the environment called 'destruction in the plant and animal world in significant size'. While this destruction covers damage where restoration to the previous state is not possible ${ }^{11}$, it must also be of significant size, but this latter condition is

7 Council Directive 92/43/EEC of 21 May 1992 on the conservation of natural habitats and of wild fauna and flora (OJ L 206, 22.07.1992, p. 7-50). Accessed September 12, 2019. https://eur-lex.europa.eu/ legal-content/EN/TXT/?uri=CELEX\%3A31992L0043.

8 Council Directive 79/409/EEC of 2 April 1979 on the conservation of wild birds (OJ L 103, 25.04.1979, p.1-18). 1979. Accessed September 12, 2019. https://eur-lex.europa.eu/legal-content/EN/ ALL/?uri=CELEX\%3A31979L0409.

9 Council Regulation (EC) No. 338/97 of 9 December 1996 on the protection of species of wild fauna and flora by regulating trade therein (OJ L 61, 03.03.1997, p. 1-69). 1996. Accessed September 12, 2019. https://eur-lex.europa.eu/legal-content/EN/ALL/?uri=celex\%3A31997R0338.

${ }_{10}$ Council Directive 79/409/EEC of 2 April 1979.

11 Judgment of 24 June 1993, signature act III KRN 98/93, LexPolonica no. 302836, OSNKW 1993, no. 9-10, item 64. Accessed September 12, 2019. https://sip.lex.pl/orzeczenia-i-pisma-urzedowe/orzeczeniasadow. 
not specified in the penal code (Radecki, ed. 2010b; Zębek 2017). Article $181 \$ 2$ provides the second condition of criminal responsibility for criminal penalty by causing significant damage related to the destruction of plants or animals in a protected area and Article 181 $\$ 3$ legislates for plants and animals under species protection.

Article 187 adds protection of the natural value of a legally protected area or object. Although specific definitions of "area and object" are not addressed in Polish legislation, the law on nature of 16 April 2004 (LJ of 2020, item 55) ${ }^{12}$ protects national parks, nature reserves, landscape parks, areas of protected landscape, nature monuments, archaeological sites, ecological sites, landscape with nature complexes and Natura 2000 sites. The crimes in this group are legislated under Article 188 which penalizes acts of building a new facility or expanding an existing one, conducting business that poses a threat to the environment in a protected area of nature or scenery, or in a buffer zone construction in violation of these prohibitions. The Polish Penal Code sanctions these offenses against the environment with a maximum penalty of imprisonment for up to five years, and up to two years for unintentional acts. The major objects of protection are therefore the plant and animal species and the natural values of protected areas. This applies to all activities that negatively affect these environmental elements and actions that cause significant damage to plants and animals are also considered in illegal waste-handling, ionizing radiation and radioactive materials. These are penalized in Articles 183-185 and they are examined in greater detail later in this article. However, the PPC lacks provisions penalizing illegal trade in protected species regulated in the aforementioned 2004 Act on Nature Conservation.

Crimes against natural environment values and protected areas in the Czech Republic are legislated in Sections 299-306 of the CPC (Radecki 2009; Zębek, Kulbacka-Burakiewicz 2017). These sections legislate crimes against the required protection of wild animals, herbs and protected areas. The following illegal activities cover:

- the unauthorized and negligent disposal of protected wild animals and herbs including their killing, destroying, processing, import, export, transit, handling and it details species directly and critically endangered by extinction or extermination species of an animal or plant with a limit of 35 individuals;

- damage to protected components of nature includes damaging or destroying a commemorative tree, significant landscape element, cave, special protected area, Euro-significant location or a bird nesting area which causes the natural value to become expired or substantially impaired;

- maltreatment of animals in an especially cruel or agonising manner or negligent omission of animal care causing long-lasting consequences to its health or death,

- poaching and hunting game or fish of a value not insignificant or handling hunted game or fish of significant value without authorisation;

- wrongful manufacture, possession or disposal of pharmaceuticals, hormones and other substances which affect the well-being of livestock by manufacture, import, export, transit, sale or otherwise obtainment or handling a substance of thyreostatic, gestagenous, androgenic, estrogenic or other hormonal effects, beta-

12 Ustawa z dnia 16 kwietnia 2004 r. o ochronie przyrody (t. j. Dz. U. z 2020, poz. 55). 2004. Accessed March 12, 2020. https://isap.sejm.gov.pl/isap.nsf/download.xsp/WDU20040920880/U/D20040880Lj.pdf. 
agonists or another substance designed to stimulate the efficiency of livestock or a preparatory containing such a substance without authorisation; or

- spreading contagious animal disease in interest stock-breeding or wild animals, as well as causing or increasing the risk of introducing or spreading of a contagious disease or parasite of utility herbs.

The list of crimes against natural values is much wider in the CPC than in the PPC, and some provisions of the directive are faithfully transposed. This especially applies to the unauthorized and negligent disposal of protected wild animals and herbs, with a precise number of species, causing irreversible loss of natural value. The legislator also lists specific objects in protected areas. These include commemorative trees, landscape elements, caves and Euro-significant bird locations (Natura 2000 sites) ${ }^{13}$. Similar to the PPC, the CPC's premises for these crimes regulate significant damage or destruction of their natural values. There is also an expanded scope of animal protection against abuse, poaching, deterioration of the welfare of farm animals by possible dangerous substances including hormones and the prevention of infectious diseases. In Poland and Germany, this is regulated by separate provisions such as the 1995 Hunting Act (LJ of 2020, item $67)^{14}$, the 1997 Act for the protection of animals (LJ of 2019, item 122) ${ }^{15}$ and the 1996 Act on maintaining municipal cleanliness and order (LJ of 2019, item 1579) ${ }^{16}$. This offense is punishable by imprisonment for up to two years, and threat and actual damage to the environment brings a maximum imprisonment of three-five years.

The group of crimes against natural environment values and protected areas in Germany is regulated in "Section 329 Endangering protected areas and 330 Especially serious offences against the environment" of the GPC (Meinberg 1998). Section 329 includes the following activities in these areas: 1) operation of facilities causing harmful environmental impacts through air pollution or noise, 2) operation of in-plant facilities relating to the handling of substances posing a water hazard, 3) operation of pipeline facilities to transport substances which pose a water hazard or transports such substances or 4) mining gravel, sand, clay or other solid substances within the framework of a commercial operation contrary to prohibition regulations. Section 329 enforces penalties for acts contrary to a statutory instrument or an enforceable prohibition enacted to protect a nature conservation area or national park: mining or extraction of mineral resources or other soil components; conducting excavations or deposits; creating, altering or removing bodies of water; draining moors, swamps, marshes or other wetlands; clearing woodland; killing, catching, hunting or destroying or removing the eggs of animals of a specially protected species or damage or removing plants of a specially protected species and the erection of building. There is therefore strong German focus on protection of Natura 2000 sites. This includes special relevance to the species' habitats listed for "wild bird species" in Annex I

13 Zákon ze dne 8. ledna 2009 trestní zákoník (Zakon č. 40/2009 Sb.). 2009. Accessed September 12, 2019. https://www.zakonyprolidi.cz/cs/2009-40?text.

14 Ustawa z dnia 13 października 1995 r. Prawo łowieckie (t. j. Dz. U. z 2020, poz. 67). 1995. Accessed March 15, 2020. https://isap.sejm.gov.pl/isap.nsf/download.xsp/WDU19951470713/U/D19950713Lj.pdf.

15 Ustawa z dnia 21 sierpnia 1997 r. o ochronie zwierząt (t. j. Dz. U. z 2019, poz. 122). 1997. Accessed March 15, 2020. http://isap.sejm.gov.pl/isap.nsf/download.xsp/WDU19971110724/U/D19970724Lj.pdf.

16 Ustawa z dnia 13 września 1996 r. o utrzymaniu czystości i porządku w gminach (t. j. Dz. U. z 2019, poz. 1579). 1996. Accessed March 12, 2020. https://isap.sejm.gov.pl/isap.nsf/download.xsp/ WDU19961320622/U/D199 60622Lj.pdf. 
of Directive 2009/147/EC 17 and for the "natural habitats for the conservation aims of these areas" listed in Annex I of Council Directive 92/43/EEC ${ }^{18}$. The maximum penalty for the above-described offenses is imprisonment for a term not exceeding five years. The German Penal Code also includes especially serious offenses against the environment under Section 330, and these are penalized by imprisonment between six months and ten years. An especially serious offense occurs where an identity is liable for: 1) interfering with a body of water, the soil or a conservation area in such a manner that the interference cannot be eliminated or only at an extraordinary expense or after a lengthy period of time and 2) permanent damage to a population of animals or plants of a strictly protected species. In order to effectively protect natural value, the German legislator focused on limiting activities that negatively affect species and habitats protected by law. In contrast to the other analyzed penal codes, the GPC legislation lists these specific activities.

\subsection{Crime of serious pollution and ionising radiation}

Directive 2008/99/EC requires member states to criminalize offenses involving environmental pollution by toxic substances and ionizing radiation (Article 3 Point a). This covers the discharge, emission or introduction of these pollutants into environmental resources such as air, soil or water which causes death or serious injury to any person or substantial damage to the quality of air, soil or water, or to animals or plants. Poland has implemented this Directive by introducing new legal provisions against air, water and soil pollution by a substance or their contamination by ionizing radiation under Article 182 (Radecki 2010a). This provision legislates the crime of pollution of the water, air or ground with a substance or radiation in such quantities that could pose a danger to the life or health of human beings and cause significant destruction to plant or animal life. Conditions of criminal responsibility for the crimes in this group are those that cause: 1) threat to human life or health, 2) significant reduction in the quality of water, air or the surface of the earth, and 3) destruction to the plant or animal world in significant sizes (Radecki 2011; Szwejkowska, Zębek 2013).

In the Czech Republic this crime is regulated in Sections 293 "Environmental Damage and Environmental Hazard", 294 "Negligent Environmental Damage and Environmental Hazard" and 297 "Wrongful Discharge of Polluting Substances" of the CPP. Section 293 includes crimes against the environment entitled "Damage and environmental threat". This states the condition of criminal responsibility for damage or endangering soil, water, air, forest or another component of the environment to a large extent or on a large area, in such a way that it may cause serious detriment to health or death, and if significant expenditures are necessary to remove the effects of such conduct. Section 294 legislates against unintentional damage and environmental hazard which endanger the protection of environmental components. Acts subject to sanction are those damaging or threatening the air, water, soil or other environmental components resulting from gross negligence and contrary to other legal provisions. These offenses result in: 1) damage or endanger-

17 Directive 2009/147/EC of the European Parliament and of the Council of 30 November 2009 on the conservation of wild birds (OJ L 20, 26.01.2010, p.7-25). 2009. Accessed March 12, 2020. https://eur-lex. europa.eu/legal-content/EN/TXT/?uri=CELEX\%3A32009L0147.

${ }_{18}$ Council Directive 92/43/EEC of 21 May 1992 on the conservation of natural habitats and of wild fauna and flora (OJ L 206, 22.07.1992, p. 7-50). 1992. Accessed March 15, 2020. https://eur-lex.europa.eu/ legal-content/EN/TXT/?uri=CELEX\%3A31992L0043. 
ment to soil, water, air, forest or another component of the environment to a large extent or on a large area, 2) serious detriment to health or death, 3) significant expenditures to eradicate the effects of such conduct. Acts of gross negligence are also subject to sanction when they cause consequential damage or a threat to an environmental component and this negligence hinders its mitigation or reversal. However, Section 297 includes the unlawful discharge of polluting substances. The main conditions of criminal responsibility for these crimes are the following: a) grievous bodily harm, b) serious and extensive harm to quality of water, animal or herbal species or parts thereof, or c) damage to the environment where significant expenditures are necessary to reverse the effect. In this way, the legislator drew special attention to the danger of substances most adversely affecting humans, waters, flora and fauna. In addition, the condition of criminal responsibility for the crime is damage of such an extent that its removal requires large financial resources. This, however, is not further specified.

In Germany, this group of crimes is legislated in Sections 330 "Especially serious offences against the environment" and 330a "Causing severe danger by releasing poisons" of the GPP. This especially applies to placing another person in danger of death or at risk of serious damage to health or subjects a large number of people to risk of damage to health or causes another person's death. An especially serious offense occurs when an identity is liable for endangering the public water supply and action is committed out of avarice. In this case, the condition of criminal responsibility places another person in danger of death or at risk of serious damage to health or places a large number of people at risk of damage to health or causes another person's death. Section 330 includes special directives in 330 a, b and c. Section 330a complements Section 330 provisions cited above with offenses causing severe danger by releasing poisons and this is further supplemented by diffusing or release substances which contain or can produce poisons, and thereby causes the danger of another person's death or results in serious damage to another person's health or there is a risk of damage to a large number of people's health. Section $330 \mathrm{~b}$ covers remorse for actions in penalty determination and Section 330c addresses confiscation of facilities and the right to act. These crimes are penalized by imprisonment between six months and ten years. This is a similar approach to crimes classified as causing a threat to human health and life as well as damage to environmental resources. Moreover, Germany sanctions this with a higher penalty when the crime results in the risk of damage to the health of a large number of people.

\subsection{Crimes of illegal waste management and shipment}

The 2008/99/EC directive mandates member countries to criminalize acts involving illegal management and shipment of waste under Articles 3 b) and c). Waste management includes the collection, transport, recovery or disposal of waste which causes or is likely to cause death or serious injury to any person or substantial damage to the quality of air, soil or water as well as to animals or plants. Moreover, the illegal shipment of waste applies to activities determined in Article 2 (35) of Regulation (EC) No. 1013/2006 of the European Parliament and of the Council of 14 June 2006 on shipments of waste ${ }^{19}$. Illegal ship-

${ }_{19}$ Regulation (EC) No. 1013/2006 of the European Parliament and of the Council of 14 June 2006 on shipments of waste (OJ L 190, 12.07.2006, p. 1-98). 2006. Accessed September 12, 2019. https://eur-lex. europa.eu/legal-content/EN/ALL/?uri=CELEX\%3A32006R1013. 
ment includes any shipment of waste effected: 1) without notification to all competent authorities concerned pursuant to this Regulation; 2) without the consent of the competent authorities concerned; 3) with consent obtained from the competent authorities concerned through falsification, misrepresentation or fraud; 4) in a way which is not specified materially in the notification or movement documents; 5) in a way which results in recovery or disposal in contravention of the Community or international rules; 6) contrary to Articles 34 (export prohibited except to EFTA countries), 36 (exports prohibition), 39 (exports to the Antarctic), 40 (exports to overseas countries or territories), 41 (imports prohibited except from a country Party to the Basel Convention or with an agreement in place or from other areas during situations of crisis or war) and 43 (imports prohibited except from an OECD Decision country or a country party to the Basel Convention or with an agreement in place or from other areas during situations of crisis or war); 7) in the case of waste being discovered not listed in Annexes III, IIIA or IIIB, or not specified materially in the document set out in Annex VII.

Illegal waste management in Poland is regulated in Article 183 of the PPC (Raniszewski 2012). This sets the new criminal provisions for inadequate waste management and shipment in implementing the provisions of this directive. Article 183 penalizes unsuitable waste management in processing waste utilization, recycling, storage, disposal, transport and shipment, which cause a threat to human life or health, significant reduction in the quality of water, air or the surface of the earth, and destruction to the plant or animal world to a significant extent. In addition, the act of importing hazardous waste from abroad or abroad without the required notification, permit or against its conditions is penalized. This act is punishable by imprisonment from six months to eight years $(\$ 5)$.

The Czech Republic legislates illegal waste management and shipment in Section 298 "Unauthorised Waste Disposal" of the CPP. This Section includes that unauthorized waste disposal provides infringement of legal regulation on disposal with waste by transporting waste across state borders, as well as storing waste or depositing, transiting or otherwise disposing of it.

The German Penal Code penalizes this crime under Section 326 "Unauthorised waste management". The unauthorized waste management crime legislates activities contrary to the authorized procedures of collection, shipment, treating, utilization, storing, depositing, discharging and disposing of waste. This applies to waste that a) contains or can produce poisons or disease agents which constitute a public danger and can be communicated to humans or animals, b) are carcinogenic, mutagenic or toxic to reproduction in humans, c) are prone to explode, spontaneously combustible or radioactive. Moreover, these activities cause long-lasting contamination or otherwise negatively alter a body of water, air, soil or endanger an animal or plant population. Here, the legislation considers the list of activities included in waste management from collection to disposal. It defines their properties, such as radioactivity, which all have a negative impact on air, waters and soil environmental resources and on fauna and flora.

There are both similarities and differences in the different countries' approach to unlawful waste management. While the relevant codes mention all stages of waste management from collection and shipment to disposal, special conditions are required in Poland for these activities to be classified as crimes. These conditions consist of endangering human health and life, deterioration of water, soil and air quality and destruction in the plant and animal world to a significant extent. The situation in Germany is similar, but the 
GPP includes carcinogenic and radioactive properties in compliance with the EC directive. Moreover, these illegal activities were already considered a criminal offence in the Czech Republic.

\subsection{Crimes of illegal procedures with nuclear materials and radioactive substances}

Directive 2008/99/EC obliges member states to legislate criminal sanctions for illegal conduct with nuclear materials and radioactive substances including their production, processing, handling, use, holding, storage, transport, import, export or disposal which cause death or serious injury to any person or substantial damage to the quality of air, soil or water as well as to animals or plants (Article $3 \mathrm{c}$ ).

The Polish Penal Code introduced these provisions in Article 184. Offences cause damage from ionizing radiation and nuclear material, and Article 184 identifies transgressions in transport, collection, storing, recklessness or neglect without properly securing any nuclear material or other source of radiation that could pose a danger to the life or health of human beings, or cause significant destruction to plant or animal life.

In contrast, this crime is penalized in the CPP under Chapter VII "Generally Dangerous Criminal Acts" in Sections 281 "Unauthorised Production and Possession of Radioactive Substances and Highly Dangerous Substances" and 282 "Unauthorised production and possession of nuclear material and special fission material". Section 281 legislates crimes including the manufacture, import, export, transport and handling of highly radioactive substances or hazardous substances without authorization. These are sanctioned by imprisonment for one to five years, to a pecuniary penalty or to prohibition of activity depending on the gravity of the offence. If offenders cause grievous bodily harm, commit such an act to a great extent or gain substantial profit, they shall be sentenced to imprisonment for two to ten years or have their property confiscated. Subsequently, Section 282 penalizes the activities in the same form, but crimes associated with nuclear materials are punished by imprisonment for two to ten years.

In Germany, the crime is regulated under Section 328 "Unauthorised handling of radioactive substances and other hazardous substances and goods" of the GPC. This Section regulates the unauthorised handling of radioactive substances and other hazardous substances and goods. This includes producing, processing, storing, or otherwise using, importing or exporting nuclear fuels and other radioactive substances which their nature, composition or quantity are a) causing another's death or serious damage to another's health or b) causing serious damage to animals or plants, bodies of water, the air or soil through ionising radiation, $c$ ) are activities without the required permit or contrary to an enforceable prohibition. There are additional penalties for failure to safely "deliver nuclear fuels, deliver nuclear fuels or the substances to unauthorised persons, cause a nuclear explosion or induce another to commit of these offences, as well as all activities of hazardous goods management (transport, shipment, packing, unpacking, loading or unloading). Thus, the protection of people and the environment against negative effects of radioactive substances has been significantly strengthened.

A nuclear facility was defined in Section $330 \mathrm{~d}$ as a facility for the production, treatment, processing, fission of nuclear fuels or for the enrichment of irradiated nuclear fuels. Moreover, hazardous goods are defined under the "Transportation of Hazardous Goods 
Act" (Gesetz über die Beförderung gefährlicher Güter) (Meyer 2012). Therefore, the three analyzed codes consider all illegal activities related to nuclear material that threaten people and environmental resources are criminal offenses. In addition, Germany penalizes illegal nuclear fuel delivery and nuclear explosions.

\subsection{Operation of a plant engaged in dangerous activities}

Directive 2008/99/EC Article 3 d obliges member states to criminalize acts related to the unsafe operation of equipment. This involves the operation of a plant where a dangerous activity is carried out or where dangerous substances or preparations are stored, used and which cause death or serious injury to any person outside the plant or any substantial damage to the quality of air, soil, water, animals or plants. Although the Polish Penal Code does not directly criminalize this crime, Article 186 legislates crimes contravening a duty. This duty is proper maintenance and use of equipment protecting the air, water and ground from pollution and radiation. The first two conditions of criminal responsibility can be assessed by monitoring, and contravention of this duty includes exceeding emission standards and reducing their quality.

While these regulations are not legislated in the CPC, the GPC includes them in Section 327 under "Unauthorised operation of facilities". This Section legislates the unauthorized operation of facilities where there is 1) operation, decommissioned or substantial modification to a nuclear facility, 2) a facility where operation has been prohibited in order to protect against hazards, 3) a pipeline facility for the transportation of water-polluting substances, 4 ) a waste disposal facility and 5) a sewage treatment facility without the required permit. Here, the activity mainly concerns nuclear facilities, and it can be considered supplementary to the sewage treatment installation and waste utilization crimes legislated under Section 328 of the GPC.

\subsection{Ozone-depleting substances}

Directive 2008/99/EC also provides for criminalization of illegal proceedings with ozone depleting substances during their production, use, marketing and importation or exportation under Article 3 e. However, study of the analyzed penal codes has established that these were legislated only in provisions of the CPC. Section 298a legislates the "Unauthorised Production and other Disposal of Substances Damaging the Ozone Layer". This condition of criminal responsibility covers the market introduction, import or export of substances which damage the ozone layer or illegally dispose of them.

In Polish legislation, these provisions are regulated by the Act of the $15^{\text {th }}$ of May 2015 on substances that deplete the ozone layer and on certain fluorinated greenhouse gases (LJ of 2019, item 2158 as amended) ${ }^{20}$. Article 52 (1) penalizes the production, use, marketing, import or export of ozone-depleting substances against the prohibitions or without complying with the conditions set out in the Act and in Regulation (EC) No. 1005/2009 of the European Parliament and of the Council of 16 September 2009 on

20 Ustawa z dnia 15 maja 2015 r. o substancjach zubożających warstwę ozonową oraz o niektórych fluorowanych gazach cieplarnianych (t. j. Dz. U. z 2019, poz. 2158 ze zmianami). 2015. Accessed March 12, 2020. http://isap.sejm.gov.pl/isap.nsf/DocDetails.xsp?id=WDU20150000881. 
substances that deplete the ozone layer ${ }^{21}$. These offences are punishable by a fine, restriction of liberty or imprisonment for up to two years.

\subsection{Damage to environmental resources}

Additional crimes not directly indicated by Directive 2008/99/EC but regulated in particular in the Czech and German Penal Codes are crimes which cause damage to environmental resources. The CPC regulates the protection of waters and forests in Sections 294a "Damage to Water Source" and 295 "Damage of Forest". Section 294a addresses "Damage to a water resource", where special criminal law protection is imposed on crimes related to water. These include acts that damage water resources in protected zones and gross negligence which substantially impairs the water resource or its specifically intended protection. Section 295 of the Penal Code legislates against crimes that damage forests. These include causing serious damage to a forest or larger forest area by harvesting forest crop or other activity contrary to legal regulation for a cleared cutting. Therefore, applicable activities are those that damage or endanger soil, water, air, forest or another component of the environment and can be caused by operating a facility where dangerous activity is conducted or where dangerous substances or compounds are stored or used without an authorisation according to another legal regulation. The value of environmental damage is assessed in $\$ 138$ of the Penal Code, where damage exceeding an insignificant amount is estimated at 5000 crowns, damage exceeding a small amount is 25000 crowns, greater damage is 50000 crowns, significant damage is 500000 crowns and extreme damage is 5000000 crowns (Radecki, ed. 2010b; Zębek, Kulbacka-Burakiewicz 2017).

The GPC legislates the pollution of water, soil and air in the following Sections: 324 "Water pollution", 324a "Soil pollution" and 325 "Air pollution". The offenses in Germany include contamination of a water body or otherwise negatively alter its properties (Section 324). This regulation, however, does not apply to material discharge into water which is likely to cause substantial damage to the quality of water without detrimentally altering its qualities (Heger, Kelker, Schramm, eds 2014). The definition also applies to soil pollution from introducing or allowing substance release or penetration. Further, Section 324a legislation includes causing damage to the health of another, animals or plants, other property of significant value or a body of water, as well as to a significant extent. German legislation has thus linked soil pollution with the likelihood of its impact on water, water plants and reservoirs. Section 325 addresses air pollution offenses related to facility operation which causes damage to the health of another, animals or plants or other property of significant value outside the area belonging to the facility or the release of harmful substances in significant amounts into the air outside the grounds of the facility. Here, harmful substances are defined as substances that result in damage to the health of another, animals or plants or other property of significant value or permanently contaminating or otherwise negatively and permanently altering a body of water, the air or soil. In addition, Section 325a covers noise pollution involving vibrations and non-ionizing radiation during the operation of a facility which endangers the health of another, animals outside the

${ }^{21}$ Regulation (EC) No. 1005/2009 of the European Parliament and of the Council of 16 September 2009 on substances that deplete the ozone layer (OJ L 286, 31.10.2009, p. 1-30). 2009. Accessed March 15, 2020. https://eur-lex.europa.eu/legal-content/EN/TXT/?uri=celex\%3A32009R1005. 
area belonging to the facility of significant value. The maximum penalty for the abovedescribed offenses is imprisonment for a term not exceeding five years.

\section{Conclusions}

Directive 2008/99/EC has established a new legal framework and standards in the field of environmental protection, and this strengthens criminal sanctions. Although the directive represents improvement, the implementation of provisions in member states' criminal codes do not meet expectations. The analysis of the effectiveness of the implementation of the Environmental Criminal Directive provisions revealed a lack of consensus in countries of the EU. Some countries have fully introduced these provisions in their criminal codes, while others have only partly sanctioned environmental crimes against air, water and soil pollution. Some have also encountered problems in enforcing crimes resulting from improper monitoring, and a further challenge is the low number of prosecutions and inadequate convictions (Ćemalović 2016; Luttenberger, Luttenberger 2017; Pereira 2017). This is further compounded by a lack of experts in environmental protection and toxic substance pollution (Faure 2017). Consequently, the directive has not been fully transposed in the $27 \mathrm{EU}$ Member States and its overall objectives not achieved. Practice has also overridden principle in that only minor corrections and additions have been made to criminal environmental law instead of comprehensive protection intended by the directive (Duțu 2016).

M. Faure notes that "mere criminalization of environmental harm forced by Directive 2008/99 does not solve the implementation deficit". The directive only requires member states to create criminal offences (or maintain already existing ones) for the breach of environmental obligations outlined in existing EU environmental legislation. The mere existence of criminal provisions does not immediately mean that these provisions are effectively implemented in practice (Faure 2017). In addition, the public consultation on the evaluation of Environmental Crime Directive conducted by the European Commission at the end of 2019 and the beginning of 2020 showed that the respondents in a meaningful proportion stated that the directive had no contribution on the member state level. According to the respondents, the directive has not contributed to more resources allocated to member states law enforcement and judicial authorities ${ }^{22}$.

Directive 2008/99/EC introduced significant changes to the criminal law affecting the environment of many EU countries. Nevertheless, despite the resulting extension of criminal provisions and further tightening of sanctions, the problem lies in the law enforcement of the amended provisions, which creates many challenges (Solodov, Zębek 2020). One of the issues is in providing clarity of the legal regulations. This is quite apparent in Poland, the Czech Republic and Germany, where all three countries implemented the main directive expectations, but they concentrated on different environmental aspects and sanctions to a greater or lesser degree.

It is very important to define and clarify the conditions of criminal responsibility for environmental crime. The three countries have slight differences in their premises.

22 "Evaluation Report of Directive 2008/99/EC of the European Parliament and of the Council of 19 November 2008 on the Protection of the Environment through Criminal law, Document no. 1580742". 2019. EC. Accessed December 4, 2019. https://eur-lex.europa.eu/legal-content/EN/TXT/?uri=pi_com:Ares (2019)1580742. 
Polish legislation specifies the following conditions of criminal responsibility for these crimes of: 1) destruction in the plant and animal world in significant size and significant damage for natural environment components and 2) threat to human life or health and significant reduction in the quality of water, air or the surface of the earth. However, group (1) is not precisely defined in Polish legislation. Similarly, the concept of significant reduction in environmental components is also unclarified, and therefore the meaning of significantly exceeded emission standards and environmental quality can only be presumed. The Czech criminal code specifies the following conditions of criminal responsibility for environmental crimes: 1) damage or endangering soil, water, air, forest or another component of the environment to a larger extent or on a large area, 2) cause serious detriment to health or death, 3) damage to the environment which requires significant expenditures to restore. Here, in contrast to the Polish code, the area parameter and the cost for restoring the environment are introduced in their classification of a criminal act, and the premises of these offenses are strictly defined in the Czech Criminal Code where larger area, damage and costs are carefully assessed in a graded manner. Moreover, the German criminal code legislates the following conditions of criminal responsibility for environmental offenses: 1) significant damage and 2) causing damage to the health of another, to animals or plants, other property of significant value in regard to a water body and other environmental components. This also includes crimes outside facility areas caused by ionising radiation and wastes. The comparison illustrates similar conditions of responsibility in these national criminal codes, especially for environmental damage in large sizes. However, only the air, water, soil and flood protection damage are clarified and negative impacts from installation activities are generally beyond their scope. Germany's transposition of Directive 2008/99/EC provisions confirms the general tendency to extend criminalization in national environmental law to comply with the new EU standards. However, similar to Poland and the Czech Republic, the conditions of criminal responsibility for German environmental crimes are not fully defined.

Analysis of the criminal code provisions in these countries highlights both similarities and differences in their approach to environmental infringements. The first group of analyzed crimes against natural environment values protects plant and animal species and the natural value of protected areas. However, the approach to these crimes in Poland is too general because it covers only the destruction of habitats and species by human activities, including those in protected areas. In addition, except for the illegal buildings legislated in the PPC, there are no specific regulations that match those in the GPC.For example, there is no mention in the PPC of installations emitting noise or posing a threat to flooding or gravel extraction. Moreover, although the GPC legislates stronger protection against illegal activities in Natura 2000 areas, the CPC correctly imposes the directive of punishing illegal possession and trade of protected species, and this expands the legal protection to animals and plants. Their code protects animals against deleterious effects of pharmaceuticals and other substances on livestock efficiency and it also provides plant protection against contagious disease and parasite spread. Thus, a different scope and extended protection are regulated in the CPC Penal Code, and this is reinforced in its other provisions. The crimes of serious pollution and emitting ionising radiation are treated with a similar approach to crimes causing a threat to human health and life and damage to environmental resources. When the crime in Germany causes a risk of damage to a large number of people's health, it is sanctioned by a higher penalty, but the CPC premise goes 
much further. In addition to the crime being judged on the amount of damage caused, the $\mathrm{CPC}$ regulates the costs for removing or alleviating the damage, but it does not specify actual amounts.

The analyzed countries all thoroughly implemented the crime of illegal waste management and shipment in their penal codes. However, while they mention the stages of waste management from collection and shipment to disposal, both Poland and Germany only classify infringements as crimes when there is waste endangerment to human health and life, deterioration in water, soil or air quality or flora and fauna destruction. In addition, although the GPC did extend the scope in these areas by specifying criminality for waste carcinogens and radioactivity, every illegal activity in waste management is considered a crime in CPC legislation. Finally, however, there is a consensus in all three analyzed countries that all illegal activities related to nuclear materials and radioactive substances that threaten people and environmental resources are criminal offenses. However, only the GPC law extends the range of these activities to illegal nuclear fuel delivery and nuclear explosion, and it directly legislates that dangerous operation of a plant is a crime. This activity mainly concerns nuclear facilities, but it is supplemented by GPC Section 328 for necessary action on sewage treatment installations and waste utilization.

The CPC invokes a similar response to crimes committed by ozone-depleting substances, and it is the only one of the three countries which penalizes these by imposing strict control on environmental damage resulting from ozone depleting substances. While the CPC regulates the intended offenses established in the 2008/99/EC directive more stringently than the Polish and German criminal codes, these countries punish the infringements in separate Acts. In addition, both the CPC and GPC sanction damage to individual environmental resources, but they employ different terminology. The Czech criminal code specifically controls environmental harm to water resources and forests with precise sanctions dependent on the extent of environmental damage and the GPC legislates pollution of water, soil and air dependent on its impact on water, water plants and reservoirs.

Punishment for illegal acts against the environment is also similar in the analyzed penal codes. For example, while the general maximum penalty for the offenses described in the above-mentioned countries is imprisonment for a term not exceeding five years, there are noticeable differences in other penalties. While unintentional acts in Poland are sanctioned by up to two years imprisonment, the Czech Republic adds legislation for environmental damage resulting from gross negligence with imprisonment for up to two years and the German Penal Code legislates for especially serious environmental offences by enforcing a period of six months to ten years imprisonment.

In conclusion, these three countries have been relatively successful in comprehensively implementing the Criminal Directive provisions. This has extended the scope of their environmental protection against acts causing the greatest degree of harm to their resources, and by extension, this has reduced the risk to human life and health. Moreover, these countries have achieved this by adapting their specific legislative and political situations. Finally, the greatest problem remaining for Poland, the Czech Republic and Germany is their vague premises covering environmental crimes. Therefore, the following postulates de lege ferenda can be formulated. There is an urgent need for the following: 
- clarify the premises for offenses against the environment and provide a definition of significant damage to the environment and destruction of flora and fauna that both the judicial system and the offender can work with;

- financially estimate significant damage to the environment and specify the costs that can be recovered in repairing it;

- define critical emission standards for water, air and soil resources, so that their excess results in an environmental crime;

- extend the scope of contamination by assessing vibrations and electromagnetic radiation;

- specify activities in protected areas, and especially in Natura 2000 sites, that threaten the objects of their protection. This will enhance the protection of objects, species and habitats;

- include animal protection and protection against ozone-depleting substances;

- crimes against the environment should be codified in one legal act - the penal code. Additional environmental legal acts should then only regulate administrative sanctions.

Finally, the combination of these legal solutions and the extension of their scope will enhance comprehensive protection of environmental resources and effective implementation of criminal provisions.

\section{References}

Cardwell, Paul J., Duncan French, Matthew Hall. 2011. “Tackling environmental crime in the European Union: the case of the missing victim?" Environmental Law and Management 23(3): 113-121.

Ćemalović, Uros. 2016. "Harmonisation of Serbian national legal system with European Union acquis — the case of environment". Economics of Agriculture 3: 891-904.

Duțu, Mircea. 2016. "European Union law. Environmental crime in the EU: is there a need for further harmonisation or for new enforcement tools?" Law Review 1 (1): 81-96.

Farmer, Andrew, Michael Faure, Grazia M. Fagliasindi. 2017. Environmental Crime in Europe. Oxford, Hart Publ.

Faure, Michael, Franziska Weber. 2017. "The Diversity of the EU Approach to Law Enforcement - Towards a Coherent Model Inspired by a Law and Economics Approach”. German Law Journal 18 (4): 823-880.

Faure, Michael. 2017. "The Development of Environmental Criminal Law in the EU and its Member States". Review of European Community \& International Environmental Law 26 (2): 139-146. https://doi. org/10.1111/reel.12204.

Gouritin, Armelle, Paul de Hert. 2009. “Environmental Crimes: An Overview”. Environmental Law Network International 1: 22-27.

Heger, Marin, Brigitte Kelker, Edward Schramm, eds, 2014. Festschrift für Kristian Kühl. München, Verlag C. H. Beck.

Jančaŕová, Irena. 2011. "Several remarks to criminal liability of legal persons to environmental protection". Czech and European Environmental Law, eds Milan Damohorský, Vojtěch Stejskal, 59-68. Praha, Nakladatelství Eva Rozkotová Publ.

Keene, Eli. 2015. "Compliance with the EU Environmental Crime Directive in the Countries of Southeast Europe and Moldova, Report, Themis Network, Austrian Development Cooperation". Regional Environmental Centre. Accessed December 4, 2019. http://documents.rec.org/publications/Themis_ Environmental_Crimes_Directive_Implementation_Report_July2015.pdf.

Kloepfer, Michael, Hans P. Vierhaus. 2002. Umweltstrafrecht. $2^{\text {nd }}$ ed. München, Verlag CH Beck.

Luttenberger, Axel, Lidija R.Luttenberger. 2017. "Challenges in regulating environmental crimes". $7^{\text {th }}$ International Maritime Science Conference, April $20^{\text {th }}-21^{\text {st }}$. Solin, Croatia. 
Meinberg, Volker. 1998. "Empirical findings on the enforcement of environmental criminal law". Zeitschrift für die gesamte Strafrechtswissenschaft 100: 112-157.

Meyer, Kirsten. 2012. "Führt $\$ 330$ d Abs. 2 StGB zur endgültigen Europarechtsakzessorietät des deutschen Umweltstrafrechts?" Wistra 1: 371-376.

Mizerová, Marie. 2011. "Criminal liability of legal persons in relations to environmental protection". Czech and European Environmental Law, eds Milan Damohorský, Vojtěch Stejskal, 69-77. Praha, Nakladatelství Eva Rozkotová Publ.

Pereira, Ricardo. 2017. "Towards Effective Implementation of the EU Environmental Crime Directive? The Case of Illegal Waste Management and Trafficking Offences". Review of European Comparative \& International Environmental Law 26 (2): 147-162.

Radecki, Wojciech, ed. 2010b. Instytucje prawa ochrony środowiska. Geneza - rozwój - perspektywy. Warszawa, Difin Publ.

Radecki, Wojciech. 2009. “Nowy czeski kodeks karny”. Prokuratura i Prawo 7/8: 185-211.

Radecki, Wojciech. 2010a. "Prawo karne środowiska. Część I.Ewolucja polskiego prawa karnego środowiskat". Journal of Ecology and Health 14 (5): 215-220.

Radecki, Wojciech. 2011. "Wdrożenie dyrektywy unijnej o ochronie środowiska”. Biuletyn Parków Krajobrazowych Wielkopolski 17 (19): 5-19.

Raniszewski, Szymon. 2012. "Dyrektywa Parlamentu Europejskiego i Rady w sprawie ochrony środowiska poprzez prawo karne oraz jej implementacja do polskiego porządku prawnego". Przegląd Prawa Ochrony Środowiska 2: 82-101.

Sina, Stephan. 2014. "EFFACE, Fighting Environmental Crime in Germany: A Country Report, Work package 2 on 'Instruments, actors, and institutions"'. Accessed February 5, 2020. https://efface.eu/sites/ default/files/EFFACE_Fighting \%20Environmental\%20Crime \%20in \%20Germany_0.pdf.

Sina, Stephan. 2017. "Environmental Criminal Law in Germany". Environmental Crime in Europe, Modern Studies in European Law, eds Andrew Farmer, Michael Faure, Grazia M. Vagliasindi, 95-118. Oxford and Portland, Oregon, Hart Publ.

Solodov, Denis, Elżbieta Zębek. 2020. "Environmental Criminal Enforcement in Poland and Russia: Meeting Current Challenges”. Utrecht Law Review 16 (2): 1-11. https://doi.org/10.36633/ulr.532.

Stejskal, Vojtěch. 2010. "New criminal regulation of environmental protection in the Czech Republic". Czech Environmental Law 4: 7-18.

Szwejkowska, Małgorzata, Elżbieta Zębek. 2013. "Environmental crimes listed in the Polish Penal Code since 1997”. International and Comparative Law Review 13 (2): 109-118.

Weber, Ulrich. 2014. “Das deutsche Umweltstrafrecht nach dem 45. StrRG”. Festschrift für Kristian Kühl, eds Marin Heger, Brigitte Kelker, Edward Schramm, 747-750. München, Verlag C. H. Beck.

Zawłocki, Robert. 2014. "Karnoprawna ochrona środowiska naturalnego". Przegląd Prawa Karnego 1: 127146.

Zębek, Elżbieta, Natalia Kulbacka-Burakiewicz. 2017. "Prawnokarna ochrona wód w świetle prawa polskiego i czeskiego". Studia Prawnoustrojowe 38: 70-85.

Zębek, Elżbieta. 2017. Instrumenty administracyjno-prawne i ekonomiczne w ochronie środowiska. Olsztyn, Kortowski Przegląd Prawniczy Monografie, Wydział Prawa i Administracji UWM Publ.

Received: October 17, 2020

Accepted: March 15, 2021

Author's information:

Elżbieta Zębek — PhD in Ecology, Associate Professor; elzbieta.zebek@uwm.edu.pl 